\title{
The Imperfect Democratic Transition in Somalia
}

\section{Mohamed Omar Bincof, PhD}

\author{
Doi: 10.19044/elp.v8no4a1 URL:http://dx.doi.org/10.19044/elp.v8no4a1
}

Submitted: 05 July 2021

Accepted: 13 December 2021

Published: 31 December 2021

\author{
Copyright 2021 Author(s) \\ Under Creative Commons BY-NC-ND \\ 4.0 OPEN ACCES
}

\begin{abstract}
The purpose of this paper is to examine the factors undermining the democratic transition in Somalia. During the first decade of independence, Somalia attempted to institutionalize a multiparty democracy. However, several factors, such as the lack of a clear political ideology, authoritarianism, and the formation of clan-based political parties, led to the decline of democratic practices, followed by a military coup and a protracted civil war. That had a devastating impact on the short and long-term democratic efforts in the country. Thirty years after the collapse of the central government, the country is embroiled in protracted political instability that continues to undermine efforts to establish formal democratic institutions and mechanisms. Apart from the political cleavage among political actors, this paper examines other factors undermining the successful transition to democracy in Somalia. It identifies factors such as the practice of clannism or a clan-based political system, rampant electoral corruption, and the inconsistent role of the international community in supporting the democratization process in Somalia. The paper argues that continuing the indirect elections has blocked the attaining successful democratic transition and stalled the adoption of procedural democracy. In addition, susceptible public institutions and instability have negatively impacted a prolonged transition in Somalia.
\end{abstract}

Key Words: Democratic, Transition, Clan-based politics, Somalia

\section{Introduction}

Modern-day African countries are states rather than nations because of failure to develop an identical national culture to support the foundation of a solid political system that could overcome their numerous domestic tribal divisions. At a fundamental level, politics in many African countries has morphed into tribalism and clan oriented. While not unique to Africa, the question of identity and politics continues to undermine efforts towards sustainable democracy. Scholars have been interested in examining the origin of ethnic politics in Africa and its impact on socio-economic spheres argued that some aspects were related to colonialism, political culture, competition for scarce resources, and bad governance as underlying causes of identitybased politics in the continent (Nzongola-Ntalaja, 1999; Berman, Eyoh \& Kymlicka, 2004; Tamarkin, 1996). 
The obstacles of burying ethnic politics and building cemented states with a solid national identity and unity have remained evident in most postcolonial African states. The Somali people, who achieved their statehood status in the Republic of Somalia, see themselves as a nation conscious of their national, cultural unity. That has saved it from the cruel tribal conflicts that the political sphere of other African states experienced. Lewis (1972) noted that linguistic and cultural differences threatened the unity of most African states and led to the expansion of family ties. The political independence movement marked the year 1950 and followed a power struggle. In Somalia, elections were assumed to influence the restructuring of the state institutions and strengthened the interest of the clans (Samatar, 1992). Though the story of the original identity is based on the system of clan membership, increasingly, the collapse of the Somali state is believed to be due to clannism, resource exploitation, and corruption.

After the collapse of the central government in 1991, the core of the conflict in the country has shifted between clan-based civil war, warlordism, and contemporary jihadism that resulted in a dysfunctional state. Similarly, the Somali clans have been viewed as a social and political system of organization and governance (Ssereo, 2003). Over the past two decades, the challenges of state-building, power struggles, and democratization in Somalia have been examined in several academic books, articles, and beyond (Last \& Seaboyer, 2011). The global response also relocated from massive military and humanitarian interventionism to pressing global democratization (Chevreau, 2017). Though the ancient and modern Somali nation plays a role in a global context, it suggested recognizing the determinants of the conflict during and after the transition (Samatar, 2007).

In the middle of 20 century, the new paradigm of social movements has appeared in global society to challenge the undemocratic system and demand democratic forms of governance. In Africa, efforts to bring about democratic reforms gained momentum in the early 1990s with demands for political pluralism to replace one-party regimes (National Research Council, 1992). Scholars refer to this period as the 'third wave of democratization. The development of this era in Somalia has been experienced with political change; however, like many other African countries, the horn of Africa's nation the movement failed in their potential to move forward after the fall of the state institutions in 1991. It is common for countries to be considered democratic; it should be characterized by an inclusive government that respects individual rights and freedoms, promotes popular participation in political decisionmaking, and regularly holds competitive elections. Unfortunately, in Somalia, the absence of multi-party democracy has restricted any group from gaining power through democratic processes (Freedom House, 2020). That passed three decades ago since the "third wave" of democratization began in Sub- 
Saharan Africa, and the impact of this wave has been mixed, with some countries have made good progress while others still face domestic challenges.

For example, a study conducted by Gabrielle \& Crawford (2011) found that democratization in Africa made progress in several areas between 1990 and 2010, while some countries reported delays. Scholars concluded that illegitimate government, persistent armed intervention, electoral irregularities, infrequent transfers of power, democratic pushback and hybrid regimes, endemic corruption, widespread ethnic voting, and insecurity sometimes negatively affect democratic progress in Africa. Ghana, for instance, has put significant efforts towards the democratization process, and it offers a story that has achieved Huntington's test of democratic consolidation (Huntington, 1991). However, numerous shortcomings remain visible, including the extreme power of the executive and the president over oversight institutions, widespread corruption among administrators and politicians, electoral disputes, the exclusion, and underrepresentation of women in political organizations, and the growing imbalance between economic growth and hunger-reduction (Abdulai, \& Crawford, 2010).

Similar inconsistent trajectories seem to emerge in Kenya when the scale of positive and negative prospects is reversed-considering that despite the lingering legacies of the 2007-2008 post-election violence and possible cases at the International Criminal Court, in addition to severe imbalances in resources and power, Kenyan nationals experience more considerable political freedoms than they did in 1980 (Cheeseman, 2011). Furthermore, Kenya has undertaken numerous reforms in the executive, judiciary, and legislature, government structure, and resource allocation under the 2010 constitution. Despite these gains, ethnicity still affects (negatively) the implementation and execution of democratic processes and principles.

The case of Somalia is an exception and showed that a complex political system. In 1991 when the military regime overthrew the power, the country was plagued by turmoil that led to a lack of government significantly influenced by the reverse democratization process.

Followed ten years without a government, in 2000, the international community organized a peace conference at Arta Djibouti with various political stakeholders participated in the political reconciliation, including women's representatives, traditional elders, civil society members, and armed members groups. That ultimately succeeded in establishing the third republic of Somalia based on a 4.5 clan structure. Since then, the country facing more severe difficulties, including rampant political corruption, foreign intervention, economic instability, high unemployment, lack of meritocracy, weak institutions, and chronic political instability (Ssereo, 2003).

The holding of direct elections has also been postponed for years, raising concerns about the possibility of a successful transition to democracy in Somalia. Above all, two decades of practicing a complicated indirect 
election model that granted clan delegates and traditional elders the privilege of exploiting the electoral process confer the power to elect members of the House of people. In contrast, the regional leaders nominated senators to the upper house and endorsed by the regional assembly (Nor, 2021). In this context, there is a need for empirical evidence that demonstrates how Somali political leaders think about democracy and have an honest desire to create a successful transition to democracy, which is a long-sought goal (Bincof, 2018). I assume that supporting the democratization process, promoting an inclusive political process, providing essential public services to citizens, and holding transparent elections are critical tasks that the past and current Somali governments have failed to deliver successfully.

Despite years of international concern, leaders have recognized "spoilers" That promote their interest instead of national interest. A report on the Electoral Crisis, published by international crisis groups mentioned that international actors punish Somali leaders as "spoilers" by imposing sanctions (Omar, 2021). The current clan political system in Somalia is unique and reflects the nature of the society; despite this cultural distinctiveness, it allows political elites to remain in power and block the political process for the reset of people who have competent and deserve to elect their leader in a competitive election. Indeed, power brokers in the country are not keen to allow inclusive and participatory grassroots elections. Instead, they extend to favor few individuals with access to political networks and resources to decide the destiny of millions of others. It is not suppressing that despite this system getting much praise from some interest groups, it has not been able to bring about the much-needed unity in the country.

In Addition, ordinary citizens, foreign countries, and international donors who support the government have long been frustrated by corrupt, dishonest, and greedy politicians who seem to maintain the status quo while attempting to weaken the transition, calling them "spoilers" (Manson, 2012). This concern is essential in addressing some obstacles that continue to disturb the credibility of the government. Thirty years of conflict means that the leadership must build political consensus and show compromise to achieve peace, stability, and development. If hardliners, self-serving individuals, and incompetent politicians continue to exploit the indirect electoral process to gain power, addressing some of the country's critical issues remains pending, such as improving security, social reconciliation, and economic development (Menkhaus, 2014).

Moreover, in line with Huntington's concept of democratic consolidation, the countries involved in the transaction must meet certain conditions that facilitate the transition from the cycle of dictatorship to democratic systems. Somalia has failed this test and is still struggling to make a successful transition to democracy in the second phase, the attempt to become a consolidated democracy where state institutions are stable, and 
democracy is no longer threatened or collapsed. This paper attempts to explore the following question in general: Why did democratic transition decline in Somalia? I will try to make the following contributions in the study: Firstly, this study sheds light on the determinants of the failure of democratic transition in Somalia. That will inform the Somali citizens, political organizations, academic communities, and the international community, which massively supports the government in various ways such as financial, technical, and peacekeeping.

The second contribution is a complex political transition; hereabouts, I explore the third wave of democratization that began in Africa at the end of the 20th century, which led to many political transformations in Africa, including Somalia in 1991. However, the efforts to bring about regime change created a vacuum in Somalia, and the democratization process went in the reverse direction. Part of the backdrop to Somalia's quest for democracy is that the country experienced ten years of prolonged civil wars without a government being registered by the United Nations.

The first promising efforts towards forming a government came in the 2000s when the country held its first indirect elections with the international community's support. Since then, democratization has been a slow process. Several elections were held through clan-based power-sharing, but never those elected administrations succussed in forming a malty-party system. Finally, the study intends to contribute to the literature on the uniqueness of the case of Somalia by identifying lessons learned from the failure of the unsuccessful transition to democracy almost 20 years. I will present some possible recommendations on how to achieve a successful transition to democracy in Somalia.

\section{Theoretical Framework}

This study analyzes the democratization theory presented in 1991, which explains various transitions from transitional to consolidated systems over time (Huntington, 1991). Mainly address the 'transitional phase' where the article investigates the factors undermining the democratic transition in Somalia. The democratization theory aims to promote regime liberation and political transition that led to consolidating democracy.

Modern political science has developed a sophisticated vocabulary for understanding democratization processes (O'Donnell \& Schmitter, 1986; Linz \& Stepan, 1996). They have helped to lay the theoretical foundations for our current understanding of politics around the globe. The theoretical democratization approach served as a guide for many studies that sought to examine the democratic transition since the late 1990s. 
LIBERALIZATION

PHASE

Successful passed but

went to reverse

direction in 1991

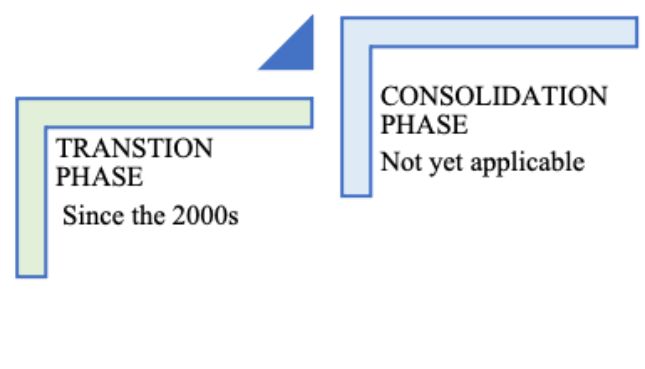

Source Author (2021)

Figure 1: illustrates the three stages of democratization proposed by (O'Donnell \& Schmitter, 1986; Linz \& Stepan, 1996), also studied by Huntingtin, 1991. As the figure shows, Somalia failed in the first stage, the liberalization of dictatorship, but the armed forces to put the country in the reverse direction led to a civil war that lasted ten years.

The nation has been struggled to make a successful transition to democracy for many years. It expects to achieve future democratic consolidation is when the stability of democracy is achieved, and there is no longer any danger of democratic systems disintegrating. That does not apply to the current scenario of the state. That will come when the second stage, transitional democracy, is successfully established.

The Arab Spring revolutions, for example, did not lead to a successful transition to democracy. However, political change has led to much confusion and distrust of the word "transition." Arab leaders brought it into the field against the movement to prevent democratic transition. Although most Arab societies support democracy, the anti-democratic opposition in the Arab world has created a class that uses religion and patronage to stay in power. Therefore, the confrontations of the regimes and the formation of economic, political, and military allies have created obstacles to the democratization of Arab society. That led to the democratic process in Egypt to solve the double dilemma of radical Islamic fundamentalism and the politicized armed elite (Laz, 2014).

From an African perspective, democratization efforts and successes are comparatively low, so the succession of elites is paramount. Somalia remains "unconsolidated" without offering a predictable position of governments, leaders, or even state structures (Schmitter, (n.d). This article uses the explanatory qualitative method to explore the reasons for the problem rather than providing answers. The article uses explanatory research, analyzes the democratization theory, extensively examines previous literature, and combines the current case study scenario. 


\section{Clan Based Political System}

Multiparty democracy developed in Somalia in just nine years, from 1960 to 1969 , which was recognized as the first democratic country on the continent and experienced a peaceful transfer of power (Samatar, 2016). General elections were held in 1964 and 1969, in which 12 to 64 political parties participated, with all parties represented by clan or subclan descent. In the elections held in late 1969, nearly 1000 candidates contested the 123 available seats. The Somali Youth League had the most public support for a single party divided along clan lines (Archives, 1969). As one of the few democratic countries, it was recognized that Somalia was fast falling into a divisive clan-party political system. However, this electoral trend was halted by a coup the following year and replaced by 22 years of non-democratic rule and decades of civil war.

This section examines the role of clans in political organizations. The clan is an informal organization consisting of a network of people linked by kinship ties. However, informal systems of politics, especially grassroots organizations, have not been sufficiently studied. That means that their role and influence in shaping regime change, or political developments are often ignored. Family ties are at the heart of identity; these ties can be both vertical and horizontal, relating to elite and non-elite groups. They reveal both real blood ties and fictional kinship: a created or metaphorical family based on close friendships or marriage ties that redefine the boundaries of genealogical unity (Kathleen, 2004). Significantly, pre-colonial political life in Somalia was based on two essential and contested principles. One is kinship (family ties) and the social contract (Tol iyo Xeer). Kinship or consanguinity was based on the decent local system where people traced their families back to common male ancestors. The second is the system of clans, which worked as corporate political associations since they were related by blood. However, blood kinship was not enough to create a political system. The clans acted as corporate political associations that negotiated a social contract that recognized promoting common unity. In this regard, clan structure divides into four main Clans and small united subclans known as 0.5.

Figure : 1 Somali Clan Structure

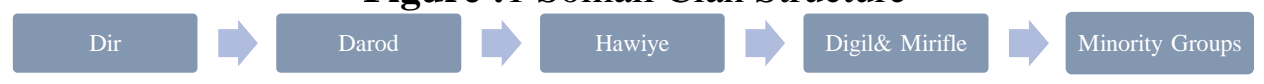

The above figure shows the current Somali clan structure.

Historically, the Somali clan structure was built without regard to the political complexities that challenged the Somali state. Clan politics will never completely disappear from Somali political life; clans are the fundamental elements of Somali society. However, to continue the progress made in the post-conflict cycles, the constraint that led to political fragmentation in 1969 
must be maintained. Conflicts and civil wars ensued, with many clan militias fighting for political power. It was easy to see clannism as one of the primary roots of the conflict and ongoing chaos in Somalia. Indeed, today, clans are the leading players in Somali politics. The current clan power-sharing structure 4.5 resulted from Conference at Arta Djibouti: Under this system, four main clans allocated equal shares of the government power, and minority clans received 0.5 . late indirect elections 2016, were participated in 14,025 clan delegates (voters) who elected the 275 members of the house of the people. The nascent federal system in Somalia faces massive challenges such as clannism and electoral corruption.

On the other side, there is a growing concept that elites and nonelites are associated with each other. Generally, elites receive support from their network to improve their political status, defend members of their clan group, and make gains within an overarching political or economic system. In contrast, non-elites need the help of clan elders to find work, shop at the bazaar, gain access to education and money, acquire public goods in a "scarcity economy," and achieve social or political progress. A much-debated question is whether elites and non-elites benefit equally from clan politics. It has been noted that both have an incentive to maintain their ties. For example, if non-elites had to leave the network, it would be difficult to survive outside a clan and marry another clan with no identity ties (Menkhaus, 2018). Today, elites have entrenched themselves in Somalia's political and social structure. As a result, they have strategically positioned themselves to influence the power and distribution of resources. In other words, the elites can better understand that they have at least some accesses to the resources flowing through the state across clan and factional lines. Each elite is linked to a clan family enjoy a monopoly on power, resources in the regional member states where their clan family dominates; an understanding that the distribution of power among elites is blessed in the form of proportional representation, known in Somalia as the "4.5 formula." Though minority groups have less advantage of this system.

In Somalia, political elites seek the support of elders and clan delegates in elections. Conversely, non-elites seek incentives from elected parliamentarians and ministers when appointing high-level officials such as directors-general, ambassadors, army commanders, and other senior management positions (Bincof, 2020). That helps MPs maintain their ties to clan elders and their followers by giving jobs to people within their clan alliance. Of particular concern is that elites are stymied by political participation while assumption looks to stay in power in the long run and limit the opportunity to participate others in political activities.

Horvitz \& Nehs (2020) pointed out that equal political participation is a fundamental feature of liberal democratic theory, which assumes that government protects its citizens with diverse political interests. The 
controversial clan perquisite is one of the critical factors that have ruined Somalia's public administration. Thus, the lack of qualified civil servants appointed to public institutions is causing chaos the country social, political, and economic sphere. Ayee (2015) emphasized that public sector reform in Somalia is doomed by discriminatory recruitment, rampant corruption, lack of accountability, and a complicated mix of over-politicization in public institutions. Ismail (2018), for example, argued that the type of politics practiced in the country has emerged through clannism, with each clan using the clan as protection and powerful tool to exploit others, adding that the system fosters a culture of robust opposition politics that goes beyond the politics of small clans.

\section{Weak Public Institution}

In a fragile state, corruption and illegal activities ultimately drive the imperfection of democratic transition. While in some cases, corruption further weakens the effectiveness of institutional performance, driving a cycle of corruption and delicate institutions that is not easy to remedy. Buzan (1993) noted that an ineffective institution often shows instability and a loss of popular support. Whereas corruption affects the ability of the state to meet its economic and social obligations to its citizens. Nearly two decades of external institution-building efforts in Somalia have yet to result in the formation of a functioning government (Menkhaus, 2014).

For decades, institution building in Somalia depended on foreign support, which spent a vast sum of money on institution building, leading to some little progress. Ken (2014) has noted that the role of external actors in institution building in Somalia has been ineffective.

According to the World Bank (2018), Somalia needs to overcome its development challenges to maintain its distinctive course. Scarce resources and minimal trust in government prevent the state from providing the public goods and services it needs to consolidate its legitimacy. While critical recurrent breakdowns (drought) threaten the country's overall progress, continued political and institutional development shows that Somalia is recovering from instability and ongoing trauma (World Bank, 2021). Institutional fragility is at the core of the country's endemic social, economic, and political situation; systematic failure in government policy formulation and implementation (HESPI, 2013).

The originally disenfranchised resist power by threatening violence, especially when opportunity preference is low, as in failure. Although democracy cannot consolidate because it is redistributive and elite subversion are extremely unbalanced communities and less likely to strengthen democracy and may end up fluctuating between regimes and allowing intense economic discord (Robinson \& Daron, 2001). Huntington says that the transition to democracy is related to the personal factor: 
"Democracies are not shaped by problems, only by their creators" (Huntington 1991) pointed out that the transition is based on preferences, but the consolidation found on the agreements and consensus between elites. Importantly, democracy is a popular system of government that holds accountable for those in power and increases public confidence in government institutions. Indeed, institutionalization depends on the ability of successful and leading politicians to conduct a credible, open, and fair election that validates democratic government. Nevertheless, corruption is one of the significant obstacles to thriving democracy and entrenching the value of democracy (Lawal, 2015). Similarly, corruption in the judicial system creates an environment where people who feel excluded from their political and social rights cannot turn to the courts. Wealthy elites have complete control over nondemocratic societies.

\section{Elections in Somalia}

Holding fair and free elections becomes problematic for a successful political transition in Somalia as the goal of achieving credibility in the electoral process to maintain the honesty and legitimacy of a democratic regime remains an unattainable goal (Isma'ila \& Othman, 2016). After 1990, competitive party elections were held in Africa to elect executive and parliamentary assembly positions leadership. However, irregularities and corruption in the elections disrupted the integrity of the elections. Somalia is overrun by electoral corruption.

An indirect election for parliamentarians is a complicated process. For instance, in the last presidential election in 2017, candidates offered much cash to bribe voters. Some reports also revealed that MPs received large sums of cash to secure their votes (Hassan, 2017). According to the New York Times, politicians disclosed money worth hundreds of dollars to buy votes. Others have agreed to the deal, been bribed, or threatened (Gettleman, 2017). The country was ranked 179 out of 180 , making it the most corrupt nation in the world (Transparency, 2020). As we can see in Table 1 below: Before the war, Somalia (1960-1991) developed a multiparty democracy; there were two constitutional referenda from 1961 to 1979 , four parliamentary elections (1964, 1969, 1979, and 1984), and one presidential election (1986). The only government that can be justified as a multiparty democratic election is the 1964 and 1969 general elections. In all other elections, a one-party system prevailed, in which voters were not free to choose their preferred political leaders freely.

Table 1: Election held in Somalia between 1960 and 1991.

\begin{tabular}{llll} 
Year & Type of elections & Total voters & Electoral \\
\hline 20 June 1961 & $\begin{array}{l}\text { Constitutional } \\
\text { Referendum }\end{array}$ & $1,943,451$ & Not applicable
\end{tabular}




\begin{tabular}{|c|c|c|c|}
\hline 30 March 1964 & Parliamentary & $914,069 *$ & Multi-party \\
\hline 26 March 1969 & Parliamentary & $782,234 *$ & Multi-party \\
\hline 25 August 1979 & $\begin{array}{l}\text { Constitutional } \\
\text { Referendum }\end{array}$ & $3,605,490$ & Not applicable \\
\hline 30 December 1979 & Parliamentary & $3,985,838 * *$ & Single party \\
\hline 31 December 1984 & Parliamentary & $4,220,466^{* *}$ & Single party \\
\hline 23 December 1986 & Presidential & $4,889,078^{*}$ & Single party \\
\hline
\end{tabular}

Table 2. In the post-conflict period in Somalia, it Shows that five indirect elections (based on a clan-based political system 4.5) have been held since the 2000s.

\begin{tabular}{|c|c|c|c|}
\hline Date & $\begin{array}{l}\text { Type of (s) } \\
\text { election }\end{array}$ & $\begin{array}{l}\text { Electoral/Selection } \\
\text { Model }\end{array}$ & Electorate \\
\hline \multirow[t]{2}{*}{$\begin{array}{l}26 \text { August } \\
2000\end{array}$} & Presidential & Indirect & $\begin{array}{l}238 \text { Members of } \\
\text { Transitional } \\
\text { National } \\
\text { Parliament }\end{array}$ \\
\hline & Parliamentary & $\begin{array}{l}\text { Indirect ( } 4.5 \\
\text { formula) }\end{array}$ & Clans \\
\hline $\begin{array}{l}10 \text { October } \\
2004\end{array}$ & Presidential & Indirect & $\begin{array}{l}275 \text { Members of } \\
\text { Transitional } \\
\text { Federal } \\
\text { Parliament }\end{array}$ \\
\hline $\begin{array}{l}30 \text { January } \\
2009\end{array}$ & Presidential & Indirect & $\begin{array}{l}425 \text { Members of } \\
\text { Transitional } \\
\text { Federal } \\
\text { Parliament }\end{array}$ \\
\hline
\end{tabular}




\begin{tabular}{|c|c|c|c|}
\hline & Parliamentary & $\begin{array}{l}\text { Indirect }(4.5 \\
\text { formula) }\end{array}$ & Clans \\
\hline $\begin{array}{l}17 \text { August } \\
2012\end{array}$ & Parliamentary & $\begin{array}{l}\text { Indirect ( } 4.5 \text { clan } \\
\text { formula) }\end{array}$ & 135 clan elders \\
\hline $\begin{array}{l}10 \text { September } \\
2012\end{array}$ & Presidential & Indirect & $\begin{array}{l}271 \text { members of } \\
\text { the Transitional } \\
\text { Federal } \\
\text { Parliament }\end{array}$ \\
\hline $\begin{array}{l}\text { November- } \\
\text { December } \\
2016\end{array}$ & Parliamentary & $\begin{array}{l}\text { Lower House - } \\
\text { indirect } \\
\text { Upper House - } \\
\text { indirect } \\
\text { (Cont.) }\end{array}$ & $\begin{array}{l}\text { FMS } \\
\text { Assemblies }\end{array}$ \\
\hline February 2017 & Presidential & Indirect & $\begin{array}{l}329 \text { Members of } \\
\text { the Upper and } \\
\text { Lower Houses } \\
\text { of the federal } \\
\text { Federal/National } \\
\text { level } \\
\text { parliament }\end{array}$ \\
\hline
\end{tabular}

Sources: Table 1: Reprinted election held in Somalia between 1960 and 1991(p.3) Crouch, J and Njag. S (2017: p.6).

Table 2 above shows that a clan-based political system 4.5 formula has been practiced in Somalia for almost two decades. Let us consider the first transitional government that was established on August 22, 2004. Due to political instability and external pressure, President Yusuf resigned in December 2008, and former parliament speaker Madowe became the acting president. The Transitional Federal Government and the Alliance for the ReLiberation of Somalia faction led by the former Sharif agreed on a political power-sharing arrangement in Djibouti. They formed the second interim government in 2009. That led to both the opposition and government wings agreeing to increase the number of parliamentary seats to 275 ; the total number of MPs was increased to 500 MPs. The mandate of the interim government 
was ended in 2012. At the same time the new constitution was adopted, the number of MPs was reduced from 500 to 275. The new constitution articulates three arms of the government. It gives a four-year term for parliament and presential offices based on clan-power sharing based on the (4.5) clan formula. Members of the House of the People are elected through electoral colleges selected by 135 traditional elders.

The last indirect election was held in 2017; 14025 electoral delegates elected the country's lower house and upper house nominated by regional presidents and approved by the regional assembly. Again, On September 17, 2021, the federal and state governments have agreed on the same indirect election model used in 2016. Clan-based electoral colleges of 101 were doubled pervious was voted by 51 clan delegates, 101 delegates will vote on each seat in the lower house, while regional assemblies will vote on seats in the Upper House. Most clan delegates and elders were accused of demanding or receiving the money to vote for candidates (Agenda \& Dialogue, 2020). That is because every government completes its term without implementing the promises made during the election campaign. This shows that initially, the leaders have failed to take the necessary steps to secure fair elections: Adoption of the legal framework, political reconciliation, national voter registration, improving security, completion of the draft professional constitution, and establishment of political parties eligible to contest elections. Indirect voting had become a monopoly system for political elites who wanted to stay in power and exclude the political space from the public. Somalis deserve a new electoral system that encourages the formation of political parties so that citizens can participate in political activities.

In other words, ethnically diverse nations have created new electoral systems after conflicts, such as Iraq, Rwanda, and Afghanistan (none of these countries are considered true democracies, the elites still control the elections). So, the apparent clarification to Somalia's electoral challenge makes more sense to focus on the electoral system to solve the clan politics that dilute the reason people hold elections in the first place. The point is to elect leaders whose economic, social, and political agendas will transform the country; this must be done in the post-conflict transition period. Moreover, the adoption of this paradigm implies a desire to move away from the clan-based political system. It allows minority parties or existing alliances to contest elections and even reach the highest position in government, which is not provided for in the current 4.5 system.

\section{The Role of Donors for Promoting Democracy in Somalia}

Following social demands for political reform, donor requirements for structural adjustment for good governance have been fundamental to Africa's third wave of democratization (Crawford \& Lynch, 2012). Though foreign 
donors are somehow promoting democratic consolidation rather than transition to multiparty democracy, which has been considered insignificant, notwithstanding the oft-cited commitment to "democracy promotion." Indeed, the analyses indicate that foreign aid has tremendously weakened democracy in some Africa (Brown \& Stephen, 2001).

More fundamentally, Carothers \& Thomas (2007) noted that donors' commitment to democracy is inherently contradictory and that "behind the rhetoric lies the persistent experience of a highly confused political existence. The international donor agencies have built up a small group of elite nongovernmental organizations with no democratic legitimacy. However, they can serve as proxies for donors by steering the policies of elected governments in a direction consistent with donor policy options, economic liberalization, and private sector growth (Michael \& Walle, 1992). The reality, however, is that non-governmental organizations set themselves upon the ground and pretend to promote democracy, but they want to take donors' money and create jobs for themselves. A study found that non-governmental organizations in Somalia face several common difficulties, including domestic decisionmaking processes, recruitment, accountability, and fundraising activities. While some of the NGOs engaged in preparing false documents to complete a project to access donor funds. Some locals refer to them as "letterbox NGOs" that survive only on paper to get their owners' money. They must work for the benefit of society (Ali, 2014). Osman reported that today's civil society organizations are extremely top-heavy in the eyes of fascinating Somalis and essentially serve donor interests. Even though numerous Somalis understand that civil society serves the interests of citizens and turns as a counterbalance to the government, others perceive the idea as different or inspired by donors and Western interests (Osman, 2018). Menkhaus (2007) noted that broader work on restructuring governance and political institutions is essential, whether at the national or international level and that further assessment of current arrangements is needed.

Interestingly, the protracted conflict and the state-building process have been an opportunity to open comprehensive the aid efforts of the global community. As the state-building initiatives were mainly externally driven and supported, the political patronage was externally driven as it was assumed not to be accountable to the Somali people. The formation of a federal government proved very difficult in 2012 as elections were held in the country for the first time in many years. That helped the newly elected government bring in international partners that resulted in the New Deal Program for Somalia is an overarching framework between the new authorities, the international community, and civil society to identify and implement preferences for peace and state-building (Chevreau, 2017). The prospects of citizens for international cooperation and support funds were primarily left out. There was little indication of public support for federalism and democratization or 
whether such reforms fit Somalia's cultural norms.

The concept of democracy is not currently relevant to Somalia; instead, the used clan-based political system for 20 years which power are distributed through 4.5. However, in early 2021, the long-awaited vision, the federal government's leadership, and federal member states put at the obstacles on promoting fair, free elections.

That prompted many international partners supporting Somalia's statebuilding and democratization to criticize the approach and call ending indirect election (Gavin, 2021). Because of the stalemate in the elections, the World Bank indicated that it would lift the funding freeze if the country did not hold elections. This warning seems to have helped in the search for a political solution (Sperber, 2021).

Somalia's federal government leadership has asked foreign partners not to interfere in the country's internal political affairs (Kahiye, 2021). Opposition leaders - including two former presidents - have recently criticized the parliament's extension of the president's term as a mere power grab. They criticize Somalia's Western partners for giving the president the green light-or at least the appearance of doing so-to interfere in the state's interests and politicize the national security forces (Sperber, 2021). The EU expressed concern about ongoing political conflict and stability and urged political leaders not to undermine political dialog or manage their internals rather than promote the interests of citizens. They have been informed that the European Union will put measures for leaders who use political violence and bear the consequences of their actions (EUEAS, 2021).

At present, the EU's role in promoting the democratization process in Somalia is considered essential. It is believed to have spent millions of dollars on state-building, peacebuilding, and humanitarian aid. For example, an agreement between the EU and the member states assisting Somalia from 2015 to 2020 includes more than 3.5 billion euros, including development aid, humanitarian aid, and peacekeeping operations (EC, 2018). Many understood that EU diplomatic pressure advanced Somali political actors to sit down at the negotiating table to reach a political consensus on their differences. They eventually accepted the electoral model and signed an agreement for the upcoming elections.

\section{Conclusion}

International actors have systematically initiated the prospect of the state restoring an already fractured federal system. After 20 years of democratic transition supported by the international community, political conflict or instability, a power struggle between regional and federal leaderships, and massive electoral corruption have increased dramatically.

Somali clans imply that the different groups have diverse interests, and for that reason, can only manage their social issues through significant reforms 
at the domestic level. That is why the nation needs to rethink diversity and find a middle ground to accommodate each person's ideas, thoughts, and philosophy. If decentralization leads to more peace, then should give it a chance, which the impact would enable the solidarity created by clannism to promote the prosperity of Somalis. As demonstrated in the country, the forms of agendas financed by donors and the institutional framework supported have appeared further coexisting with the external actors, contrasted to the Somalis who were not compliant.

Moreover, the clan-based political system has produced numerous interest groups, mainly seen as new elites from the diaspora; their dual citizenship has resulted from inconstancies of domestic and foreign policies. That increased local conflicts between politicians and officeholders. At the same time, Diasporas took over most government posts, including the president, the MPs, and the prime minister, and dominated even senior advisors let empty with local politicians/citizens who were eager to join public institutions.

Despite these controversial arguments, this study offers some insights into the factors undermining the democratic transition in Somalia. Much more work will be needed to determine the application of procedural democracy in Somalia. The country needs to rethink its clan heterogeneity and find a middle ground that puts its interests first. Therefore, the study suggests that the country develop a formal transition plan (roadmap) to guide the elected leaders in implementing procedural democracy. However, Somali leaders are pursuing their interests instead of promoting the national interest and genuinely fulfilling the mandate given by the constitution.

The study notes that many challenges hinder democratic transition, including lack of political commitment, poor democratization choices by elites, and persistent political instability between the federal government and federal member states, as well as the clan-based political system. Somalia suffers from an informal political structure involving various groups and actors who use public offices for personal interests, which has resulted in a dysfunctional state. The role of the international community contributes only insignificantly to the achievement of a thriving transitional democracy. It believes that foreign countries do not have a common agenda to support a successful democratic transition in Somalia. For example, some Gulf states have interfered in the country's internal politics and are widely considered to be providing money to presidential candidates during the election campaign. Also, some other international powers are widely seen as supporting presidential candidates to steer profitable business opportunities, bolster an austere variant, or spy on U.S. forces (see New York Times, by Gettleman, 2017). 


\section{References:}

Abdulai, G., \& Crawford, G. (2010). Consolidating democracy in Ghana: progress and prospects? Democratization, 17 (1), 26-67.

Ali, M.A., (2014). The sinking feeling in Somalia: The trouble with nogs in the horn of Africa. https://www.peaceinsight.org/en/articles/

Acemoglu, Daron, and James A. Robinson. 2001. "A Theory of Political Transitions." American Economic Review, 91 (4): 938-963.

Agenda \& Dialog (2020). Protecting Stability and inclusivity in Somalia's indirect election process, Somali dialog platform briefing \& Somali public agenda governance. https://reliefweb.int/sites/reliefweb.int/file

Archive, S. (1969). Somalia elections: Election report (March 26, 1969. http://archive.ipu.org/parline-e/

Ayee, J. (2015). Commonwealth association for public administration and management, commonwealth Innovation's review. 21(3), September 2015, Ottawa, Ontario, Canada K1N 7E5.

Bincof, O. (2020). The effect of public sector reform on good governance in Somalia. Journal public policy and administration research, 10 (9), 69-77.

Bincof. (2018). The role of youth in political participation in Somalia. IOSR journal of humanities and social science (IOSR-JHSS), 23(10), 2: 64-74.

Bratton, Michael, and Nicholas van de Walle. 'Popular Protest and Political Reform in Africa.' Comparative Politics, 24 (1992): 419 -42.

Brown \& Stephen. (2001). Authoritarian leaders and multiparty elections in Africa: How Foreign Donors Help to Keep Kenya's Danielarap Moi in Power'. Third World Quarterly, 22 (2001): 725- 39.

Buzan, B. (1983). People state \& fear; the national security problem in international relations. GREAT BRITAIN, Wheatsheaf books Ltd, Sussex.

Carothers \& Thomas (2007). 'The "Sequencing" fallacy'. Journal of Democracy, 18(2), 12 -27.

Cheeseman, N. (2011). 'The Internal dynamics of power-sharing in Africa'. democratization 18 (2), $336-365$.

Chevreau, O. (2017). Federalism \& post-conflict state building: the case of Somalia (Master's thesis), University of Bradford, www.bradscholars.brad.ac.uk

Gabrielle, L. \& Gordon, C. (2011) Democratization in Africa 1990-2010: an assessment. Democratization, 18(2), 275-310.

Crouch, J. \& Njag, S. (2017). Electoral Crossroads Dilemmas of future democratization in Somalia, Dilemmas of future democratization in Somalia. https://www.saferworld.org.uk/resources/publications

Elman, C, (2005) "Explanatory typologies in qualitative studies from international politics". international organization, 59 (2), 293-326.

Gavin, M, (2021) Somalia's Political Crisis Demands Sustained Attention, Www.cfr.org

EUEAS, (2021). Somalia: Statement by the high representative/vice-president 
joseph Borrell on the current political situation https://eeas.europa.eu/delegations/somalia

EU, Commission. (2018). EU support in Somalia. Memo, Brussels. https://ec.europa.eu/

Gettleman, J. (2017) Fueled by bribes, Somalia's election seen as milestone of corruption. https://www.nytimes.com/2017/02/07/

Hassan, M. (2017). Corruption likely to mar Somali presidential vote. available https://www.voanews.com/africa/corruption

Hassan, I. (2019). Electoral corruption in Nigeria: A study of the general elections. center for democracy \& development, available at https://media.africaportal.org

HESPI, (2013). Rebuilding viable state and effective institutions in Somalia, conference proceeding August 26-28, 2013, Addis Ababa, Ethiopia, available at www.hespi.org/wp

Horvitz, A. \& Nehs, M. (2020). Equalizing Political Participation and, in turn, Political Influence with Civil Liability Rules, European Journal of Economics, Law and Politics, March 2020 edition 7(1), 2518-3761.

Huntington, S. (1991). The Third Wave: democratization in the late twentieth century. Norman: university of Oklahoma press.

Ismail. Y. (2018). Somalia's clan politics. Www.worldpolicy.org

Isma'ili, Y. \& Othman, Z. (2016). Challenges of electoral malpractices on democratic consolidation in Nigeria's fourth republic. International review of management and marketing, 6, (S8),103-107.

Kahiye, M (2021). Somalia warns envoys against meddling in political affairs. https://www.voanews.com/africa/somalia

Kathleen. C. (2004). The logic of clan politics: evidence from the central Asian trajectories. World Politics, 56, (2) 224-261.

Menkhaus, K. (2007). Governance without government in Somalia: spoilers, state building, and the politics of coping. international security, 31 (3), 74-106. Last, D. \& Seaboyer, A. (2011). Clan and Islamic identities in Somali Society. Defence R\&D Canada, Toronto CR 2011-080. https://apps.dtic.mil/sti/pdfs

Lawal, S. M. (2015). An Appraisal of corruption in the Nigeria electoral system. European scientific journal, 11 (25), 1857- 7431.

Laz, E. (2014) Sustainable democracy and the paradox of the Arab spring: The Egypt experience, alternatives Turkish journal of international relations, 13(12) (42-51) Spring- Summer 2014.

Lewis, I. M. (1972). The Politics of the 1969 Somali Coup. Journal of Modern African Studies, 10: 383-408.

Linz \& Stepan (1996) Problems of democratic consolidation southern Europe, southern America, and post-communist Europe. Baltimore: John Hopkins University Press.

Manson, K. (2012) Somalia begins an imperfect transition. Available at https://www.ft.com/content/ 
Menkhaus, K. (2018). Elite bargains and political deals project: Somalia case study, Stabilization Unit. www.assets.publishing.service.gov.uk

Menkhaus, K. (2014). State failure, state-building, and prospects for a 'functional failed state' in Somalia. The annals of the American academy of political and social science, 656: 154-172.

National Research Council, (1992). Democratization in Africa: African views, African voices. Washington, DC: the national academies press, a https://doi.org/10.17226/2041

Nzongola-Ntalaja, G. (1999). Ethnicity and state politics in Africa. African journal from international affairs, 2 (1), 31-60.

O'Donnell \& Schmitter, (1986) Transitions from authoritarian rule: tentative conclusion about uncertainty. Baltimore: The Johns Hopkins Press. Omar. M. (2021) Why Somalia's electoral crisis has tipped into violence. https://www.crisisgroup.org/africa/.

Osman, F. (2018). The role of civil society in Somalia's reconstruction: successes, challenges, and opportunities. Available www.saferworld.org.uk Samatar, I.A. (2016). Africa's first democrats: Somalia's Aden A. Osman and Abdirasak H. Hussein. Bloomington, and Indianapolis, Indiana University Press.

Samatar, A.I. (2007). Somalia's post-conflict economy: a political economy approach. Bildhaan. An International Journal of Somali Studies, 7 (8), 126168.

Samatar, A. (1992). Destruction of state and society in Somalia. Journal of Modern African Studies, 30(4), 625-641.

Schmitter, P. C. (n.d). Democratization and political elites, https://www.eui.eu Sperber, A. (2021). Back from the brink: Somalia's political crisis explained. www.thenewhumanitarian.org

Ssereo, F. (2003). Clan politics, clan democracy and conflict regulation in Africa: The experience of Somalia. The Global Review of Ethnopolitics, 2(34), 25-40.

SOMALIA, (1969). Elections March 26, 1969.www.archive.ipu.org Sosinka, C. (2020). (2014.) Colonization of Somalia. www.sites.psu.edu Tamarkin, M. (1996). Culture and politics in Africa: legitimizing ethnicity, rehabilitating the postcolonial state. Nationalism and Ethnic Politics, 2(3), 360-380.

Transparency, I. (2020) Corruption perception index: Country Somalia. Available at https://www.transparency.org/en/cpi/

Veneria, M. R. (2020). The United Nations, Italy, and Somalia: a s'ui generis' relationship 1948-1969. https://www.dspace.libary.uu.nl

World Bank, (2021). World Bank supports state institutions in Somalia to promote good governance, accelerate economic recovery, and create jobs. Available at https://www.worldbank.org/en/country/somalia/

World Bank (2018). Republic of Somalia Systematic Country Diagnostic. 
World Bank Group Document, Report No. 123807- SO federal available at https://documents1.worldbank.org/curated/pt/ 